\title{
Hunting Intensity on Wildlife Population in Oban Sector of Cross River National Park
}

\author{
G. A. Lameed', J. K. Omifolaji², A. S. Abere ${ }^{3}$, S. O. Ilori' ${ }^{1}$ \\ ${ }^{1}$ Department of Wildlife and Ecotourism management, University of Ibadan, Ibadan, Nigeria \\ ${ }^{2}$ Department of Forestry and Wildlife Management, Federal University, Dutse, Nigeria \\ ${ }^{3}$ Department of Forestry and Environment, Faculty of Agriculture, River State University of Science and \\ Technology, Port Harcourt, Nigeria \\ Email: lamgbola2008@gmail.com
}

Received 17 October 2014; accepted 19 April 2015; published 22 April 2015

Copyright (C) 2015 by authors and Scientific Research Publishing Inc.

This work is licensed under the Creative Commons Attribution International License (CC BY).

http://creativecommons.org/licenses/by/4.0/

(c) (†) Open Access

\section{Abstract}

Hunting intensity in Oban Sector of Cross River National Park, Nigeria was investigated. The methodology involved the recording of signs of hunting activity using line transects, and interviews with hunters. A total of 33 gunshots, 21 spent cartridges, 26 wire snares, presence of 7 hunters and two hunters' camps and other several hunting signs were recorded for a total of 68 km of transects walked. Nine species of mammals were hunted, notably the Chimpanzee Pan troglodytes, Mona monkey (Cercopithecus mona), Puttynose monkey (Cercopithecus nictitans), Red river hog (Potamochoerus porcus), Drill (Mandrillus leucophaeus), Brush-tailed Porcupine (Atherurus africanus), Blue duiker (Cephalophus monticla), Bushbuck (Tragelaphus scriptus), Ogilby's duiker (Cephalophus dorsalis), Western tree hyrax (Dendrohyrax dorsalis), and Grasscutter (Thryonomys swinderianus). The interviews revealed the most hunted species as the iii Primates (Cercopithecus spp 28.48\%), African brush-tailed Porcupine (Atherurus africanus) (37.74\%), Blue Duiker (Philantomba monticola) (26.82\%), Bushbuck (Tragelaphus scriptus) (6.96\%), Pangolin (Manis tetradactyla), Red river hog (Potamochoerus porcus) and Grasscutter (Thyronomys swinderianus) with the first four being the most commonly hunted. Shotguns and Wire snares were the two main hunting methods used, with the former being used $(88.24 \%)$ of all the hunters interviewed, and the latter (11.76\%) of the hunters. Each hunter set 50 - 300 wire snares, of which there were two types: 1) ground snare without fencing (neck wire snare), and 2) ground snare with fencing (foot/leg wire snares. Most of the wire snares hunting take place mainly during the raining season. The study revealed high hunting intensity in Oban Sector of CRNP. Some of the recommended measures to ameliorate the menace include the initiation of public education and awareness programmes, establishment of task forces to check bushmeat hunting, execution of stricter law enforcement, good welfare package for park rangers and more punitive sanctions for offenders. 
Keywords

National Park, Conservation, Hunting, Community, Wild Animals

\section{Introduction}

Worldwide, one of the greatest threats to persistence of vertebrates in tropical rain forests is unsustainable hunting [1]. Unsustainable hunting is of special concern in the tropical rain forests of west and central Africa, where most of the 2/3 inhabitants rely on wild animals for protein [2]. The number of animals harvested has risen throughout west and central Africa as growing and increasingly sedentary human populations have adopted more efficient hunting techniques, such as wire snares and shotguns, and increased their participation in market economies [3]. Increased hunting offtakes, as measured by number of animals killed, are more likely where extractive industries such as logging and oil exploitation attract immigrants and lead to expanded road networks, which increases consumption and trade of wild animals [4] [5]. Although the effects of hunting on population viability are well documented, understanding how heterogeneity in hunting pressure combines with variation in ecological communities and animal demographics to determine sustainability is still a challenge [6] [7]. In general most hunting occurs near human settlements [8] [9] and key access points to forests, such as roads or rivers [10] [11]. Wildlife dispersal may have considerable influence on maintenance of large harvests around settlements through source-sink dynamics [6] [12] (i.e., populations with an intrinsic growth rate $(\lambda)>1$ [i.e., sources] that are linked through dispersal to populations with $\lambda<1$ [i.e., sinks]) [13]. In the hunting literature, the term sink often refers to the area around a settlement where hunting off-takes are thought to be augmented by dispersing animals from remote less-hunted or unhunted sources of animals [6] [14]. Habitat loss, forest fragmentation and unregulated exploitation of wildlife, as a result of increasing demand for bushmeat, threatens many large mammals throughout West Africa. Over hunting has further reduced wild populations of many forest-dependent animals [15]. Hunting and bushmeat utilization are integral parts of the sociocultural traditions of many rural communities of the forest zone [16], for whom bushmeat is the most available and important source of essential proteins [17]. These activities, however, impact negatively on wildlife populations throughout the tropics [18]. Commercial bushmeat hunting results in increasing harvest rates through increased hunting intensity by local people, and immigration of non-resident commercial hunters [19] [20]. In West Africa, 25\% of the daily protein requirements of the people are from bushmeat. The study aimed to conduct an investigation on hunting intensity on large mammals' population in Oban Hills Sector of Cross River National Park, Nigeria, and to recommend ways to minimize its threat to wildlife within the Reserve.

\section{Materials and Methods}

\subsection{Study Area}

The Oban Sector of Cross River National Park was carved out of Oban Group of Forest Reserve in 1991 and located in the Cross River State, Nigeria. It lies within Latitude $5^{\circ} 15^{\prime}$ and $05^{\circ} 25^{\prime} \mathrm{N}$ and Longitude $8^{\circ} 30^{\prime} \mathrm{N}$ and $08^{\circ} 45^{\prime} \mathrm{E}$ in the south-eastern corner of Nigeria, in Cross River. It covers an area of about $3000 \mathrm{sq} \cdot \mathrm{km}$ of primary tropical moist rainforest ecosystem in the north and central parts and contiguous with Korup National Park in the Republic of Cameroon and is sub-divided into two ranges East and West. It has annual rainfall of $3000 \mathrm{~mm}$ in the southern parts and $2500 \mathrm{~mm}$ in hilly and mountainous areas from March to November with a peak in June/ July.

\subsection{Data Collection}

Oban Sector of Cross River National Park is divided into two ranges, the west and east ranges. This study was conducted in the two ranges with permission from National Park Service. Four villages were purposely selected from these two ranges within Oban Sector with two villages each from the ranges viz: From Oban west range (Obung/Netim 05 $21^{\prime} 25^{\prime \prime} \mathrm{N}, 08^{\circ} 26^{\prime} 24^{\prime \prime} \mathrm{E}$ and Ifumkpa $\left(05^{\circ} 31^{\prime} 56^{\prime \prime} .7 \mathrm{~N}, 008^{\circ} 17^{\prime} 30^{\prime \prime} .4 \mathrm{E}\right.$ ) and Oban east range (Aking $\left.05^{\circ} 25^{\prime} 67^{\prime \prime} \mathrm{N}, 08^{\circ} 38^{\prime} 10^{\prime \prime E}\right)$ and Ekang $\left(05^{\circ} 40^{\prime} 00^{\prime \prime} \mathrm{N}, 08^{\circ} 49^{\prime} 00^{\prime \prime} \mathrm{E}\right)$ based on their closeness to the park.

Thirty two transects $(2 \mathrm{~km})$ each were established using stratified sampling methods. Eight transects of $2 \mathrm{~km}$ 
each were laid in each of the four land-use types (core, buffer, farm fallow and plantation) in the study locations at $600 \mathrm{~m}$ intervals using a stratified sampling techniques and placed sufficiently far apart to avoid an object from being detected on two neighbouring transects (Buckland et al., 2001, Waltert et al., 2006).

For each of the eight (8) randomly-placed permanent transects in the land use types with average of $2 \mathrm{~km}$ per transect were walked, and signs of hunting activity, including spent cartridges, matches box, used carbide, wire snares, traps, hunting camps, hunters encountered, and gunshots heard within $10 \mathrm{~m}$ of both sides of the transects were recorded. Spent cartridges found were collected but wire snares were destroyed. The start and end coordinates of each transect were recorded, together with the positions of hunting camps located in the study area, and on-going activities within the camps. Also interview and structured questionnaires was used to obtain information from hunters in the study area on hunting methods and the types of animals hunted. The ages of spent cartridges was estimated by experienced hunters, using the criteria of extent of rust of the cartridge metal and discoloration of the plastic casing.

\section{Results and Discussion}

A total of 33 gunshots, 21 spent cartridges, 26 wire snares, 7 hunters and two hunters' camps and several other hunting signs were recorded for a total of $68 \mathrm{~km}$ of transects walked (Table 1). The hunted species include the Primates (Cercopithecus spp), Drill (Mandrillus leucophaeus), African brush-tailed Porcupine (Atherurus africanus), Blue Duiker (Philantomba monticola), Bushbuck (Tragelaphus scriptus), Pangolin (Manis tetradactyla), Red river hog (Potamochoerus porcus) and Grasscutter (Thyronomys swinderianus) with the first four being the most commonly hunted (Table 2). Shotguns and Wire snares were the two main hunting methods used (Table 3), with the former being used by $88.24 \%$ of all the hunters interviewed, and the latter by $11.76 \%$ of the hunters. Each hunter set 50 - 300 wire snares, of which there were two types: 1) ground snare without fencing (neck wire snare), and 2) ground snare with fencing (foot/leg wire snares). None of the two hunting camps identified, was active while there are several active hunting trails within the study area. Signs of current hunting activities included used batteries; matches boxes, footprints, and one motorcycle. Use of any form of traps for hunting activities were not allowed in Ekang as the community frowned at it in its entirety of it usage by locals due to the

Table 1. Evidence of hunting intensity across different land-use type in relation to wildlife population in the Oban hill sector of CRNP, Nigeria.

\begin{tabular}{cccccc}
\hline \multirow{2}{*}{ Method/Tools } & \multicolumn{5}{c}{ LANDUSE/TRANSECT } \\
\cline { 2 - 6 } & Close Canopy Forest & Secondary Forest & Farm Fallow & Plantation & Total \\
\hline Length $(\mathrm{km})$ & 16 & 16 & 16 & 16 & 64 \\
Wire snare & 9 & 1 & 15 & 1 & 26 \\
Spent cartridges & 9 & 4 & 7 & 0 & 21 \\
Hunters encountered & 2 & 0 & 5 & 0 & 7 \\
Gunshots heard & 15 & 3 & 15 & 0 & 33 \\
Number of hunters camp & 3 & 0 & 0 & 0 & 3 \\
Number of hunting trails & 10 & 3 & 0 & 0 & 13 \\
\hline
\end{tabular}

Table 2. Most commonly hunted wildlife species in Oban hill sector of CRNP.

\begin{tabular}{ccc}
\hline \multirow{2}{*}{ Common Name } & \multicolumn{1}{c}{ Commonly Hunted Wildlife Species } \\
\cline { 2 - 3 } African brush-tailed Porcupine & Species & Percentage (\%) \\
Primates & Atherurus africanus & 37.74 \\
Blue Duiker & Cercopithecus spp & 28.48 \\
Bushbuck & Philantomba monticola & 26.82 \\
Grass-cutter & Tragelaphus scriptus & 6.96 \\
\hline
\end{tabular}


Table 3. Shows percentage of tool/methods used for hunting in Oban hill sector of CRNP.

\begin{tabular}{ccc}
\hline Tools/methods & Frequency & Percentage (\%) \\
\hline Gun & 30 & 88.24 \\
Wire snare & 4 & 11.7 \\
Nets & 0 & 0.00 \\
Spear and arrow & 0 & 0.00 \\
Others & 0 & 0.00 \\
Total & 34 & 100 \\
\hline
\end{tabular}

danger posed. Majority of the interviewed hunters set wire snares mainly in the raining season due to poor feasibility and incessant rainfall which reduced offtake from the forest. The traps were checked every 2 - 3 days by the hunters, who were indigenes of the support zone communities around the CRNP villages: Obong/Netim, Ekang, Ekuri, Ndibenji, Oban, Ojor, Owai, Iko Esai and Ifumpka as both subsistence and commercial hunters. The reason for checking the traps every 2 - 3 days was that trap inspection could be time consuming, especially when large numbers of traps are set. Trap/wire snare setting is most common among the hunters during the raining season as there's less time for long hunting expedition due to constant heavy down during the period that disrupt hunting activities. Result of interview revealed that most hunting activities (79.41\%) were carried out in the core zone of the park while the remaining $17.65 \%$ and $2.94 \%$ are executed in the farm fallow and buffer zone respectively.

\section{Effect of Hunting Intensity on Wildlife Population in Oban Hills Sector of CRNP}

The study indicated high level of hunting intensity in the study area, resulting from 1) the use of unsustainable hunting methods like shotguns and wire snares, 2) high demand for bushmeat, 3) illegal logging activities in the park, and 4) lack of capacity to control hunting in the park. The current illegal logging activities in the Oban Hill sector of CRNP alters and, fragments or destroys wildlife habitat by decreasing forest cover through infrastructural development and tree felling [21] [22]. Large mammals are especially exposed and become easy targets for hunters, roads, tractors and motorcycles provide easy access to previously remote forests, enabling more and more illegal subsistence and commercial hunters to wreak havoc on the wildlife [19] [22].

Since wire snares are cheap and easy to set, hunters are able to operate them in large quantities over much wider areas. Even though shotguns are quite expensive to acquire, they are also easily available, cost effective and economically viable because they kill the larger and more profitable mammals. These two hunting methods are, however, not suitable for sustainable hunting because prey are killed almost instantly regardless of age, sex, size, species and breeding condition. The country's wildlife laws are not deterrent enough (low fines), to the extent that even where adequate staffing exists, the law enforcers are not motivated enough to arrest offenders. Oban hill sector of CRNP is among the only places with suitable habitat factors (food, shelter, and water), the highest diversity and abundance of faunal species and naturally-protected fauna and are, therefore, the greatest hope for the long term survival of such fauna population.

Lack of adequate attention to the role of bushmeat as an important contributor of local livelihoods by development agencies, non-governmental and inter-governmental organizations, and national governments contributes to the unsustainable hunting of bushmeat in tropical forests. Even when present at the national level, policy and legal frameworks to promote sustainable use of natural resources are seldom inadequate in remote rural areas. Financial, material, and training resources are insufficient to allow law enforcement personnel to adequately address the illegal commercial trade in bushmeat and this deficiency decreases the capacity for control of illegal activities. Loss of both traditional hunting territories (like those belonging to certain traditional groups) and methods (like hunting zone rotations) allow open access to the resource and concentration of hunting, thereby resulting in a loss of sustainability. Changes in traditional hunting practices through the use of improved hunting technology (such as shotguns, flashlights, outboard motors) generally decrease the probability that hunting will be sustainable since both the range of species taken, the area hunted and fatal injury rates increase. In addition the use of steel wire snares, for any species, also increase rates of indiscriminate harvest. 
Hunting rules and regulations exist almost everywhere but they are rarely enforced. There is clearly an ownership and management problem. The State is the owner of the resource and issues rules and regulation to manage it but the State is unable to enforce its decisions. A law that is not enforced undermines the authority of the government, and a law that can only be enforced at great cost and difficulty might need to be revised. There is much work to be done in order to tackle this issue in most tropical countries [23] [24].

\section{Conclusion}

In conclusion, the work centred on hunting intensity in Oban Sector of Cross River National Park, Nigeria in which the methods used were recording of signs of hunting activity using line transects, and interviews with hunters. The study shows high hunting intensity in Oban Sector of CRNP. A key conservation issue at the Oban Hills Sector of Cross River National Park is the hunting intensity on wildlife populations. Despite the fact that Nigeria's law gives full protection to endangered species, large-scale farming encroachment and illegal hunting in bushmeat and life captured wildlife including threatened and endangered species may be driving species towards local extinction at the Oban Hill Sector of Cross River National Park. The study is significant in that it promotes awareness among the local communities as well as the government of Nigeria and the international community on the current status of fauna biodiversity loss and the need to protect wildlife especially the critically endangered species within the Oban Hills Sector of Cross River National Park.

\section{Acknowledgements}

We are grateful to Volkswagen Foundation, Hanover, Germany, for financing this research, Idea Wild, USA for field Equipment and Board of Nigeria National Park Service, Abuja for permitting us to conduct this work in Cross River National Park, and staff from the park for providing Field support during the fieldwork period.

\section{References}

[1] Milner-Gulland, E.J. and Bennett, E.L. (2003) Wild Meat: The Bigger Picture. Trends in Ecology and Evolution, 18, 351-357. http://dx.doi.org/10.1016/S0169-5347(03)00123-X

[2] Wilkie, D.S. and Carpenter, J.F. (1999) Bushmeat Hunting in Congo Basin: An Assessment of Impacts and Options for Mitigation. Biodiversity and Conservation, 8, 927-955. http://dx.doi.org/10.1023/A:1008877309871

[3] Fa, J.E. and Brown, D. (2009) Impacts of Hunting on Mammals in African Tropical Moist Forests: A Review and Synthesis. Mammal Review, 39, 231-264. http://dx.doi.org/10.1111/j.1365-2907.2009.00149.x

[4] Wilkie, D.S., Sidle, J.G. and Boundzanga, G.C. (1992) Mechanized Logging, Market Hunting, and a Bank Loan in Congo. Conservation Biology, 6, 570-580. http://dx.doi.org/10.1046/j.1523-1739.1992.06040570.x

[5] Thibault, M. and Blaney, S. (2003) The Oil Industry as an Underlying Factor in the Bushmeat Crisis in Central Africa. Conservation Biology, 17, 1807-1813. http://dx.doi.org/10.1111/j.1523-1739.2003.00159.x

[6] Novaro, A., Redford, K. and Bodmer, R. (2000) Effects of Hunting In Source-Sink Systems in the Neotropics. Conservation Biology, 14, 713-721. http://dx.doi.org/10.1046/j.1523-1739.2000.98452.x

[7] Siren, A., Hamback, P. and Machoa, J. (2004) Including Spatial Heterogeneity and Animal Dispersal When Evaluating Hunting: A Model Analysis and an Empirical Assessment in an Amazonian Community. Conservation Biology, 18, 1315-1329. http://dx.doi.org/10.1111/j.1523-1739.2004.00024.x

[8] Hames, R. (1988) Game Conservation or Efficient Hunting. In: Mccay, B. and Acheson, J., Eds., Capturing the Commons: Anthropological Approaches to Resource Management, University Of Arizona Press, Tucson, 192-207.

[9] Alvard, M.S. (1994) Conservation by Native Peoples-Prey Choice in a Depleted Habitat. Human Nature, 5, 127-154. http://dx.doi.org/10.1007/BF02692158

[10] Begazo, A.J. and Bodmer, R E. (1998) Use and Conservation of Cracidae (Aves: Galliformes) in the Peruvian Amazon. Oryx, 32, 301-309. http://dx.doi.org/10.1017/S0030605300030106

[11] Peres, C.A. and Lake, I.R. (2003) Extent of Non-Timber Resource Extraction in Tropical Forests: Accessibility to Game Vertebrates by Hunters in the Amazon Basin. Conservation Biology, 17, 521-537. http://dx.doi.org/10.1046/j.1523-1739.2003.01413.x

[12] Alvard, M., Robinson, J.G., Redford, K.H. and Kaplan, H. (1997) The Sustainability of Subsistence Hunting in the Neotropics: Data from Two Native Communities. Conservation Biology, 11, 977-982.

http://dx.doi.org/10.1046/j.1523-1739.1997.96047.x 
[13] Pulliam, H.R. (1988) Sources, Sinks and Population Regulation. The American Naturalist, 132, 652-661. http://dx.doi.org/10.1086/284880

[14] Salas, L. and Kim, J. (2002) Spatial Factors and Stochasticity in the Evaluation of Sustainable Hunting of Tapirs. Conservation Biology, 16, 86-96. http://dx.doi.org/10.1046/j.1523-1739.2002.00225.x

[15] Barrie, A. and Aalangdong, O. (2005) Rapid Assessment of Large Mammals at Draw River, Boi-Tano and Krokosua Hills. In: McCullough, J., Decher, J. and Kpelle, D., Eds., A Biological Assessment of the Terrestrial Ecosystems of the Draw River, Boi-Tano, Tano Nimiri and Krokosua Hills Forest Reserves, Southwestern Ghana, number 36 in RAP Bulletin of Biological Assessment, Conservation International-Center for Applied Biodiversity Sciences, Washington DC, 67-72.

[16] Bennett, E.L. and Robinson, J.G. (2000) Hunting of Wildlife in Tropical Forests: Implications for Biodiversity and Forest People WCS New York. In: Bennett, E.L. and Robinson, J.G., Eds., Hunting For Sustainability in Tropical Forests, Columbia University, New York.

[17] Barnes, R.F.W. (2002) The Bushmeat Boom and Bust in West and Central Africa. Oryx, 36, 236-212.

[18] Bennett, E.L., Robinson, J.G., Milner-Gulland, E.J., Bakarr, M., Eves, H.E. and Wilkie, D.S. (2002) Hunting the World's Wildlife to Extinction. Oryx, 36, 328-329. http://dx.doi.org/10.1017/S0030605302000637

[19] Bennett, E.L. (2004) Seeing the Wildlife and Trees Improving Timber Certification to Conserve Tropical Forest Wildlife. Wildlife Conservation Society Paper World Bank, Washington.

[20] Buckland, S.T., Anderson, D.R., Burnham, K.P., Laake, J.L., Borchers, D.L. and Thomas, L. (2001) Introduction to Distance Sampling: Estimating Abundance of Biological Populations. Oxford University Press, Oxford

[21] Waltert, M., Heber, S., Riedelbauch, S., Lien, J.L. and Muhlenberg, M. (2006) Estimates of Blue Duiker (Cephalophus monticola) Densities from Diurnal and Nocturnal Line Transects in the Korup Region, South-Western Cameroon. African Journal of Ecology, 44, 290-292. http://dx.doi.org/10.1111/j.1365-2028.2006.00631.x

[22] Bass, M., Aviram, R. and Parker, K. (2003) Timber Certification: Prospects and Progress in Addressing Wildlife Issues in Central Africa. In: Uncertain Future: The Bushmeat Crisis in Africa, 230 p.

[23] Nasi, R., Brown, D., Wilkie, D., Bennett, E., Tutin, C., van Tol, G. and Christophersen, T. (2008) Conservation and Use of Wildlife-Based Resources: The Bushmeat Crisis. Technical Series No. 33, Secretariat of the Convention on Biological Diversity, Montreal, and Center for International Forestry Research (CIFOR), Bogor, 50 p.

[24] Jimoh, S., Alarape, A., Ikyaagba, E. and Adeyemi, A. (2012) Preliminary Information on the Density and Distribution of Duiker in the Oban Division of Cross River National Park, Nigeria. African Journal of Ecology. 